\title{
Sustainability, ideology, and the politics of development in Cabo Pulmo, Baja California Sur, Mexico
}

\author{
Ryan Anderson ${ }^{1}$ \\ University of Kentucky, USA
}

\begin{abstract}
Based upon twelve months of anthropological fieldwork in Cabo Pulmo, Baja California Sur, Mexico, this article uses political ecology and theoretical work on ideology to examine how local residents use the concept of sustainability to advocate for alternative visions of development. Conceptually, the idea of sustainability has a long, often conflicted history. As political ecologists have pointed out, sustainability can be everything from a tool of dominance and pacification to a strident defense of environment, place, and local rights. Between 2010 and 2012, the residents of Cabo Pulmo waged a campaign against a large-scale tourism development that was perceived as a threat to local livelihoods and environmental health. They deployed the concept of sustainability during this campaign, and afterwards, as a way to build local solidarity in the face of increasing development pressures. Sustainability works as a temporary ideological tool that transcends internal disputes during intense conflicts over the meaning of development.
\end{abstract}

Keywords: Sustainability, ideology, development, Baja California Sur, Mexico.

\section{Resumé}

Basé sur douze mois de travail de terrain anthropologique à Cabo Pulmo, Baja California Sur, au Mexique, cet article utilise l'écologie politique et le travail théorique sur l'idéologie d'examiner comment les résidents locaux utilisent le concept de durabilité à plaider pour des visions alternatives de développement. Conceptuellement, l'idée de la durabilité a une longue histoire, mais souvent conflictuelle. Comme les écologistes politiques ont souligné, le développement durable peut être tout d'un outil de domination et de pacification de la défense stridente de l'environnement, un lieu, et les droits locaux. Entre 2010 et 2012, les résidents de Cabo Pulmo mené une campagne contre un développement du tourisme à grande échelle qui a été perçu comme une menace pour les moyens de subsistance locaux et la santé environnementale. Ils ont déployé le concept de durabilité au cours de cette campagne, et par la suite, comme un moyen de renforcer la solidarité locale face à des pressions croissantes de développement. Le concept de durabilité fonctionne comme un outil idéologique temporaire qui transcende les désaccords internes au cours d'intenses conflits sur le sens du développement.

Mots-clés: durabilité, l'idéologie, développement, Baja California Sur, au Mexique.

\footnotetext{
${ }^{1}$ Dr. Ryan Anderson, Department of Anthropology, University of Kentucky, Lexington, KY 40506, USA. Email: ryananderson75 "at" gmail.com. I would like to thank JPE editor Casey Walsh and the anonymous reviewers for their suggestions and comments. I would also like to thank Sarah Lyon for all of her editorial suggestions and guidance on earlier drafts of this article, Keith Hart for his thoughts and input on very early versions of this work, and Alba Gámez for all of her support and advice throughout the research process. This research was supported by a National Science Foundation Doctoral Dissertation Research Improvement Grant (DDRIG \#12266992), a Dissertation Enhancement Award from the University of Kentucky, and a fellowship from the Baja Coastal Institute. Lastly, I am grateful for all of the help and support from the community of Cabo Pulmo, including the hardworking staff and membership of Amigos para la conservación de Cabo Pulmo (ACCP).
} 


\section{Resumen}

Basado en doce meses de trabajo de campo antropológico en Cabo Pulmo, Baja California Sur, México, este trabajo utiliza la ecología política y el trabajo teórico sobre la ideología para examinar cómo los residentes locales utilizan el concepto de sostenibilidad para abogar por visiones alternativas de desarrollo. Conceptualmente, la idea de la sostenibilidad tiene una larga historia, entraba en conflicto. Como trabajos recién de la ecología política han señalado, la sostenibilidad puede ser de todo, desde una herramienta de la dominación y la pacificación a la defensa estridente de medio ambiente, el lugar y los derechos locales. Entre 2010 y 2012, los habitantes de Cabo Pulmo iniciaron una campaña en contra de un desarrollo turístico a gran escala que se percibía como una amenaza para los medios de vida locales y la salud ambiental. Desplegaron el concepto de sostenibilidad durante esta campaña, y después, como una manera de construir la solidaridad local frente a las crecientes presiones de desarrollo. El autor argumenta que la sostenibilidad funciona como una herramienta ideológica temporal que trasciende las disputas internas durante intensos conflictos sobre el significado del desarrollo.

Palabras clave: sostenibilidad, la ideología, desarrollo, Baja California Sur, México.

\section{Introduction: saving Cabo Pulmo}

In Cabo Pulmo, Mexico, local community members believe in sustainability, despite the conflicted, often contradictory histories and meanings of this well-worn yet still salient concept. Far from the cynical deconstructions of many academics and development experts, sustainability, for many residents of Cabo Pulmo, points to a more hopeful, just future. It embodies a resilient hope that they will avoid the disasters, dispossessions, and degradations of mass tourism development. In this article, drawing from political ecology, theories of ideology, and anthropological fieldwork, I argue that sustainability functions as a unifying ideology for the residents of Cabo Pulmo, providing a conceptual map for social action, meaning, and solidarity in the face of impending mass development (see Eagleton 1991; Geertz 1973). It serves this purpose even while-and perhaps because-other, powerful agents continue to marshal the idea of sustainable development toward completely different ends.

In this social context, the concept of sustainability functions as a temporary ideological tool that binds residents of Cabo Pulmo together in solidarity against competing interests, while also masking internal conflicts and divisions. The idea of sustainability, often implemented as 'sustainable development', lends itself to a multiplicity of interpretations, uses, and meanings. In Cabo Pulmo, residents deploy the idea of sustainability as a way to express their desires for an alternative development future that privileges local meanings and rights above the interests of external developers and investors. The irony of the situation is this: many of the developers behind large-scale tourism development also use the same language of sustainability to define their own efforts. The difference, then, comes down to a matter of interests, on the one hand, and beliefs about what sustainability means—or should mean.

The concept of sustainability has received more than its share of critical attention from political ecologists (e.g. Adams 2009; Escobar 1995, 2008; Neumann 2005; Watts and Peet 2004). Both Adams (2009) and Neumann (2005) provide historical accounts that illustrate the development of the concept over time, and also the varied competing uses and meanings that have clouded the conceptual clarity of this ubiquitous term. Adams, in particular, highlights the differences between "mainstream" sustainable development, on the one hand, and more radical approaches (2009: 171). In the ideal sense, Adams argues, development should be shaped by who has the power to decide how it is managed, but all too often it is a reality imposed, top-down, by states, bankers, and development "experts" (2009: 379). That sustainable development often comes down to power is no surprise for political ecologists, who assert the need to foreground the importance of politics in understanding development, resource, and environmental conflicts (Bryant 1991; Robbins 2004; Watts and Peet 2004).

Sustainability is an idea laden with contradictions, which leaves it wide open for political and social manipulation. For many, the idea of sustainability conjures optimistic images of a 'better' way of doing the work of development. It is a mode of conscientious development that acknowledges the importance of 
protecting the environment and the rights and needs of future generations. On the other side of the equation, sustainable development has been adopted-perhaps more accurately co-opted - by a broad field of power brokers, including politicians, scientists, NGOs, academics, and development experts. In this light, sustainability can be seen as a controlling, manipulative exercise of power that is implemented (ironically) in the name of conservation (Goldman 2004). It's a concept that can be moulded into many forms, to serve various competing interests. It is the language of progressive change, or, conversely, a dangerous, empty deployment of that very same language that is meant to uphold current patterns of growth.

Watts and Peet (2004: xiv) characterize sustainable development as one "strategy" that is meant to alleviate the constant tension between the drive for economic growth and the desire to protect the natural environment. Sustainable development can be one of two things, they argue. First, it can be a tool of dominance and pacification. By framing economic growth in terms that people find acceptable and tolerable, sustainable development works to quell political and social discontent. In this sense, it is a sort of ideological palliative that allows for the continuation of (comfortable) patterns of growth. In this sense, the concept of sustainability works in a classical Marxist way to mystify social reality and to mask social reality (see Wolf 1999). This version, Watts and Peet argue, makes development palatable, just enough, so that people don't revolt.

But sustainable development can also work in a second sense, translating into a strident defense of environment and place through more radical politics and political action (see also Escobar 1995, 2008). The tension between these two sides of sustainability —as a tool of dominance or, alternatively, a defense of local places-is the main focus on my analysis. While the political ecological literature has explored and critiqued the concept of sustainability through numerous analytical frameworks (e.g. political economic, historical, conceptual, and discursive, among others), ideology has not, in general, been a focal point of analysis per se. True, ideology is often thought of as a key sub-component of any discourse (see Neumann 2005: 92-94), but it has not been a focal point of many political ecological analyses.

Ideology is a tricky term to work through. This is partly a result of a long, incredibly contradictory history in which the meaning of the concept has shifted dramatically. Once thought of as an objective, scientific study of ideas, today ideology is often glossed as a warped, distorted view of social reality (see Eagleton 1991; Geertz 1973; Larrain 1979; Wolf 1999). One of the dominant Marxian definitions and uses of ideology is closely related to the concept of the commodity fetish; in this sense ideology is little more than 'false consciousness.' In this light, ideologies obscure or efface accurate views of the social world. Along similar lines, Wolf defines ideology as "a complex of ideas selected to underwrite and represent a particular project of installing, maintaining, and aggrandizing power in social relationships" (1999: 55). Wolf's focus on ideology through the lens of power stems from an extended argument about culture, in which he argues needs to be understood in terms of the relationship between power and ideas (1999: 57). Wolf also argues that materialist and idealist approaches to ideology need not be opposed (1999: 58). This is where the work of Geertz, who focuses on the meanings of ideology, is a helpful addition (although I'm not quite sure if Wolf would have approved of this pairing).

For Geertz, the construction of ideology is a response to social strain. "Ideology," he writes, "bridges the emotional gap between things as they are and as one would have them be..." (1973: 205). The function of ideology, for Geertz, is to "...make autonomous politics possible" through the use of "authoritative concepts" that render meaning to social reality. Ideologies become crucial during times of social and cultural dissolution and breakdown. In this sense, ideology serves to justify the part of culture that is primarily concerned with establishing and defending beliefs and values (1973: 231).

One way to combine the concerns of both Wolf (power and social order) and Geertz (strain and meaning) is to broaden the definition of ideology to something along the lines of "any kind of intersection between belief systems and political power" (Seliger 1976, cited in Eagleton 1991: 6). But this definition doesn't quite bring us far enough. Eagleton's clarification of the differences between politics and ideology leads us to the working definition of ideology that informs the rest of this article. Politics, he argues, is the power-infused process through which social order is maintained. Ideology, on the other hand, "...denotes how power processes get caught up in signification" (1991: 11). It is, in other words, about the confluence of 
power and meaning. But ideology is not signification per se, Eagleton explains. Rather, ideology is about "conflicts within fields of signification" (Eagleton 1991:11). The question of sustainability—in Cabo Pulmo, but also in coastal destinations around the world—is one such contested field. My reading of the term seeks to move beyond strict conceptions of the term that limit it to little more than false consciousness, while, at the same time, not completely discarding its potentially mystifying capacities. Ideology is about conflicts over meaning and interests, particularly when belief plays a vital role.

Belief certainly plays a role in local deployments of the concept of ideology in Cabo Pulmo. The community sits, uncomfortably, on the cusp between radically opposed visions of sustainability and sustainable development. While the community has rallied around the idea of sustainability, it is also increasingly caught within wider, global processes of development, market expansion, and investment that pose a serious threat to community autonomy. Theirs is an uncertain future, and tourism cities such as Los Cabos serve as symbolic models of where they may be heading if development continues apace. Cabo Pulmo could become a model for just, community-focused sustainable development (see Gámez 2008 and Gerber 2008) — or it could be swept into the kind of coastal development that has dominated in Los Cabos (see López et al. 2006), Cancun (Castellanos 2010; Torres and Momsen 2005), Huatulco (Madsen Camacho 2000) and other destinations around the world. Within this milieu of social, cultural, and environmental strain, community members of Cabo Pulmo latch onto and deploy their version of sustainability as a way to encapsulate their hopes_and to fight for an alternative development future. At the moment, however, sustainability is more of a hopeful belief than a material reality.

\section{Background: Cabo Pulmo, BCS, Mexico}

Cabo Pulmo is located at the southern tip of the Baja California peninsula, approximately an hour north of the Los Cabos tourism zone (Figure 1, 2). It is home to one of the few hard coral reefs in the Eastern Pacific. The community made a transition from subsistence and small-scale fishing to an ecotourism-based economy beginning in the early 1980s (see Gámez 2008). In 1995, a Marine Protected Area was created to protect Pulmo reef and encourage local conservation. Today this MPA is part of the Cabo Pulmo National Park (CPNP). I conducted research in a region informally known as the 'East Cape' from 2009 until 2013. The East Cape is generally understood to include the coastal strip north of San Jose del Cabo up to the pueblo of Los Barriles (Figure 1). My research included two summers of exploratory fieldwork in 2009 and 2010, one year of fieldwork in 2012, and one follow up trip in early 2013. I lived and worked primarily in Cabo Pulmo, which has a population of approximately two hundred people. I conducted a total of 42 formal and 80 informal interviews with Mexican and non-Mexican residents, in conjunction with extensive participant observation with various groups directly involved in the development (and conservation) process.

Cabo Pulmo is an internationally-recognized destination for eco-tourists, travelers, divers, hikers, and others who are drawn to the region's austere desert landscape and striking marine environment. The transition from a fishing community to an ecotourism destination over the past decade has literally put Cabo Pulmo on the map, attracting more tourists, non-Mexican residents, and researchers-not to mention developers and investors. Therefore, rather than being a large-scale tourism city, many feel that Cabo Pulmo is the ideal site for a new, sustainable tourism model (see Gámez 2008; Gámez and Montaño 2004; Gerber 2008).

The development of the Cabo Pulmo National Park (CPNP) took years. It was not an instant success. The early years were fraught with a range of conflicts and logistical problems (see Weiant 2005). One of the main issues was a resistance to the park itself when it was first created. This resistance came from local members of the Mexican community, and from the expats who also call Cabo Pulmo home. Success for the park was a long time coming, but it did come: between 1999 and 2009, CPNP experienced a 463\% increase in biomass (Aburto et al. 2011). Much of this success can be attributed to local community members who embraced the park's mission. The news of this success led to a flurry of media and news reports that hailed Cabo Pulmo as one of Mexico's most successful conservation efforts (e.g. Delsol 2012; Lee 2011; Scripps 2011). 


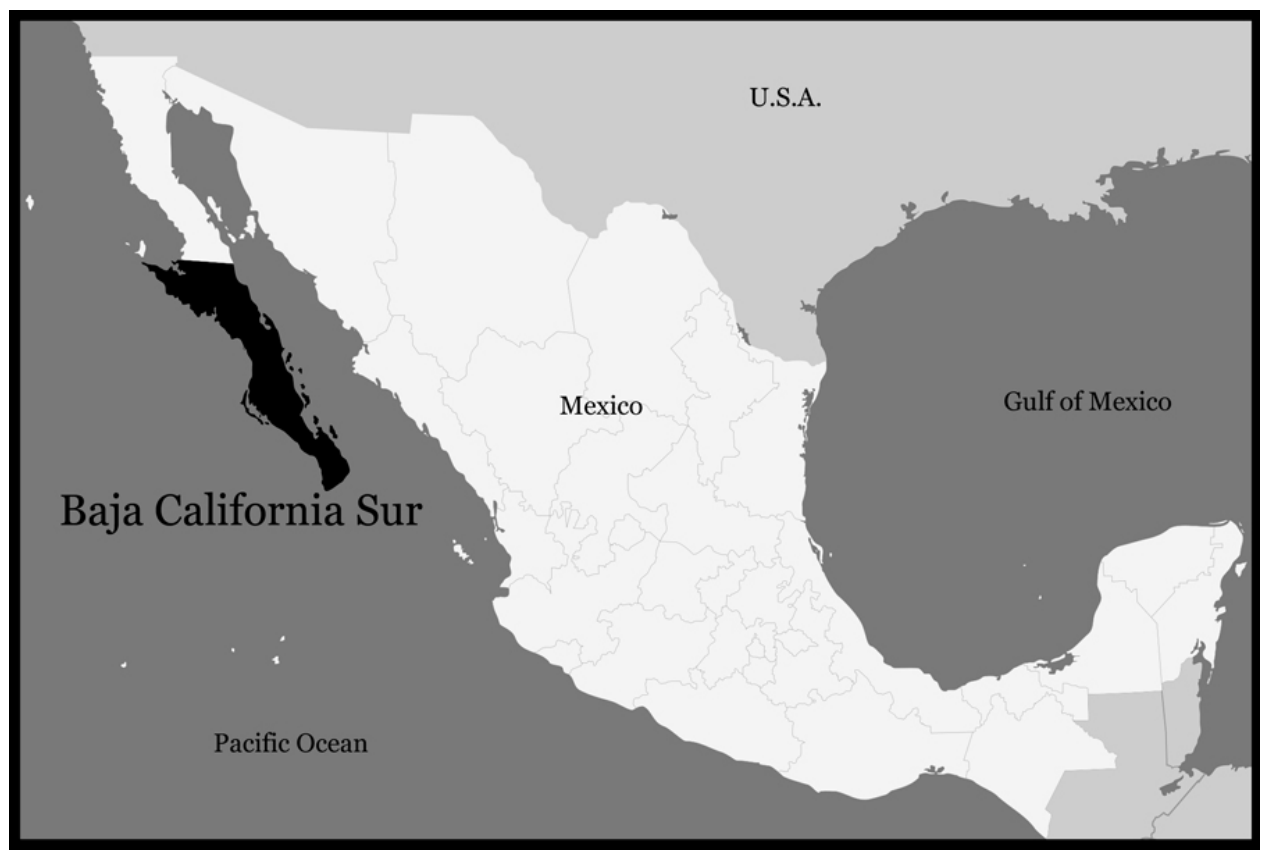

Figure 1: Location of Baja California Sur, Mexico.

While the park itself has achieved recent successes, the community of Cabo Pulmo still faces many internal social, political, economic, and infrastructural problems. The park receives national and international support and attention, but most of the local Mexican residents ${ }^{2}$ still lack many basic resources such as public water infrastructure, power, health services, schools, and even clearly defined public spaces (see Gerber 2008; Gámez and Montaño 2004). The roads are unpaved. The nearest health clinic is at least 30 minutes away-and longer if the roads are washed out. The small elementary school was destroyed in 2005 when hurricane John swept through the peninsula. All that remains is an empty, forlorn concrete shell out on Cabo Pulmo point. There is a pre-school, but the rest of the community's young students take a forty minute bus ride into the neighboring pueblo of La Ribera. As for water, while the expats have plenty (although it's not cheap), the Mexican community has been fighting to make the government build reliable water infrastructure. While the national park has received considerable government attention and support, the needs of the local community lag far behind. Some members of the community, however, are pushing back...using discourses about sustainability as primary modes of social organization.

\section{Si se puede}

Judith, a native of Cabo Pulmo, is the president of Amigos para la Conservación de Cabo Pulmo (ACCP), a community-based organization that was founded more than a decade ago. She is one of the most active members of ACCP, focusing much of her energy on preserving Pulmo reef. But her efforts are not just directed at environmental conservation. She also spends a great deal of time trying to promote and foster community development in Cabo Pulmo. When she talks about community development, she talks in terms of sustainable development.

\footnotetext{
${ }^{2}$ There are approximately 250 residents in the community of Cabo Pulmo. About 80 of them belong to local Mexican families, while 150-160 are expatriates and/or retirees from either the US or Canada.
} 


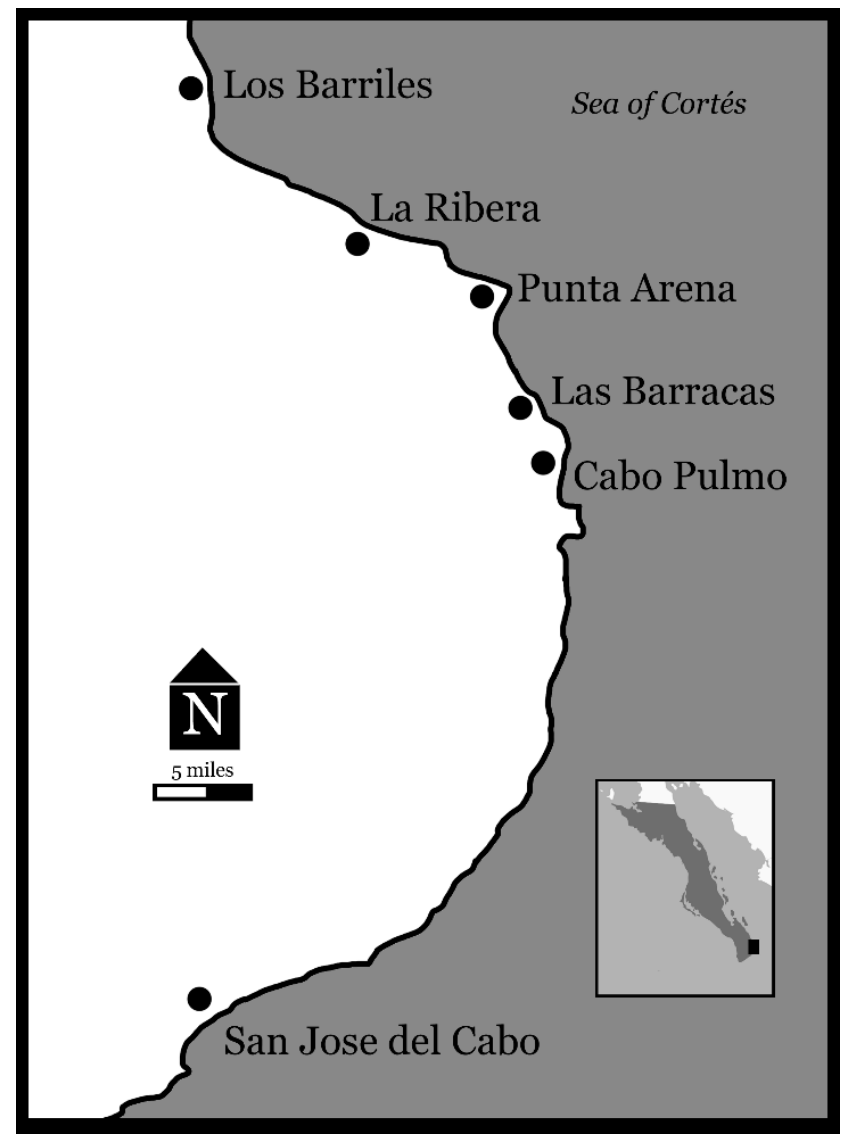

Figure 2: The East Cape of Baja California Sur, Mexico.

"The park is a success," she tells me, "but the community is what needs a lot of support now." Judith explains that the community of Cabo Pulmo needs this support to deal with and adjust to the growing tourism market. They need training, customer service skills, and certifications...but they also need adequate infrastructure for the community itself. Basic things like lights on the streets, she tells me. Judith highlights Cabo Pulmo's community development plan, which was devised with the assistance of the consulting firm Development Alternatives Incorporated (DAI) through a series of community meetings, training sessions, and presentations.

"We have a sustainable development project we're working on here," Judith explains. The idea is to make Cabo Pulmo into a "sanctuary of sea, land, and people," and a "destination that's truly ecological, authentic, and rustic." This is the slogan that the community of Cabo Pulmo came up with during their work with DAI in 2011. "It sounds very good," Judith tells me, "but it's going to require a lot of work, a lot of support, and a lot of effort to bring everyone together." The project, she says, is about what the community members of Cabo Pulmo want for themselves. The whole idea, she says, is that "we ourselves - the inhabitants of Cabo Pulmo — decide what we want...or how we want to develop Cabo Pulmo."

Judith then brought up the fight against Cabo Cortés, a mass tourism development that was proposed on the East Cape (see Greenpeace 2010). Between 2010 and mid-2012, the community of Cabo Pulmo, in partnership with a broad coalition of national and international groups, waged an extensive campaign against Cabo Cortés. "Our fight is against the scale of that project," Judith explains. "It's a project that's too big, and it's not something that's needed in this area." Cabo Cortés, she told me, would kill the reef at Cabo Pulmo. The community development plan is all about finding an alternative path. 
"So our plan is for Cabo Pulmo to offer a vision of sustainable development. Not just in Cabo Pulmo but in the whole area." This is going to require broad community agreement, she explains. They need to do everything they can to make Cabo Pulmo:

...the destination, not just another place, but the tourism destination of excellence that is sustainability. Like I said, it sounds very beautiful, but it's going to require a lot of work and commitment. From everyone who lives here. It's not going to be easy...but we have to believe si se puede (yes you can).

In order to move forward, community members first have to believe that an alternative future is possible. For Judith and the community of Cabo Pulmo, discourses about sustainability speak to the desire for local control, participation, and empowerment. But sustainability is not a reality at this point. It is part of a hopeful, imagined future. The community's sustainable development project is an idea that Judith, ACCP, and their interlocutors are using to try to build support and community solidarity. This project focuses on building local infrastructure, services, training, education, and engagement with the ideals of conservation. Locals see it as sustainable because it means they will retain access to and control of the place in which they live. Importantly, this is occurring amidst a social situation that is absolutely not sustainable at present. The community is highly divided; an insecure land title and ownership situation only makes those divisions worse.

Briefly, the insecure land issue stems from changes in Mexico's property and foreign investment laws that began in the early 1970s. The Mexican Constitution of 1917 forbade direct foreign ownership of land in the "restricted zone," which encompasses all territory within 100 miles of the border and 50 miles of the coastline (see Vargas 1994; Veteto 2014). Through the changes in foreign investment laws and the creation of legal trusts, Mexico allowed foreigners to invest in real estate in the restricted zone. This process has resulted in 1) a dramatic increase in foreign land investment in coastal real estate; and 2) much higher land values. In Cabo Pulmo, there are several ongoing property disputes that are rooted in this increase of foreign investment. In essence, some members of the Mexican community continue to dispute the validity of land transactions involving sale to foreign buyers. Because of these land disputes, much of the land is completely unavailable to local Mexican residents. This situation, in combination with high land values and cost of living, has also inhibited the development of Cabo Pulmo's social infrastructure (e.g. schools, health services, and other basic necessities. Without an accessible, secure land base, the community of Cabo Pulmo remains stuck in a highly unsustainable state.

Sustainability is ideology, then, because it is something that exists in the future-it is a hope that people hold out for. It is a hope for a better life, and for something radically different from present conditions. This hope informs actions, associations, and social movements. In local discourses, the ideology of sustainability serves as a powerful antithesis to the region's most prominent symbol of unsustainable development: mass tourism development in the tourism city of Los Cabos.

\section{Los Cabos: symbol of an unwanted future}

For many residents of Cabo Pulmo, Los Cabos ${ }^{3}$ is a symbol of the successes and failures of the 'traditional', mass-tourism models that have dominated Mexican tourism development for decades. Mexico's centrally-planned tourism 'poles', which were brought online from in the 1970s (see Clancy 2001), undoubtedly generated revenue, investment, growth, and rising economic indices, but they also came with a wide range of social, economic, and environmental costs (Castellanos 2010; Gámez 2008: 20; Gámez 2012; Hierneaux 1999; López et al. 2006; Wilson 2008).

\footnotetext{
${ }^{3}$ The word cabo means 'cape.' Many development projects use this term as part of their name, which can lead to some confusion. The contemporary tourism zone known as Los Cabos includes the cities of San Jose del Cabo and Cabo San Lucas, and the territory between these two cities. For the sake of clarity, I use the term Los Cabos but it is important to point out that these two cities have very different development histories. For more about this see Clancy (2001) and Gamez (2012).
} 
Since 1974, Los Cabos has grown to become one of Mexico's premier tourism destinations (Gámez and Ganster 2012: 255). Because of its success, it is a model for future tourism development throughout BCS and Mexico as a whole (Gámez and Ganster 2012: 253). The rise of Los Cabos led to dramatic demographic growth: the population rose from 11,481 in 1980 (López et al. 2006: 365) to 238,352 in 2010 (INEGI 2011 in Gámez 2012: 214). This growth was built through the creation of a tourism market that caters specifically to an older, affluent clientele-mostly from the United States. These travelers seek the exclusive, luxurious experiences offered by the many high-end resorts found in Los Cabos. This market orientation-toward wealthy, often retired travelers-has proven effective for drawing in tourists (and revenue) year after year. But there's another side of the exclusivity, luxury, and affluence of Los Cabos.

In 2009, National Geographic Traveler ranked Los Cabos as "...one of the worst tourism destinations in the world" (Gámez 2012: 216; National Geographic Traveller 2009:70). The rating was based upon criteria that include environmental, aesthetic, and cultural factors, including the "future prospects" of a destination (Gámez 2012: 216). The downsides of the successes of Los Cabos also include land dispossession, socioeconomic segregation, and extensive urban colonias with tremendously lower standards of living than the tourism zones (see López et al. 2006; Wilson 2008). As Gámez (2008: 20) argues, development in Los Cabos did not adequately address how urban and touristic pressures would impact the natural and social resources of the region. Primary concerns include environmental degradation, public health and safety, loss of local identity, and threats to sovereignty - the last issue particularly because of the increase of foreign residents and business owners (Gámez 2008: 20; see also Cabral 1998; López et al. 2006).

These failures of Los Cabos-perceived and real-reverberate through the social order and influence how residents of the cape region, including Cabo Pulmo, envision the future of the East Cape. Often, residents' experiences with, and opinions of, Los Cabos inform their views about projects such as Cabo Cortés, which are close to home. Los Cabos also shapes how people think about, talk about, and imagine what development means and what they think it should look like.

Angeles is the manager of La Palapa, a small, popular seaside restaurant in Cabo Pulmo. When I interviewed her in 2012, her main issue with Cabo Cortés was succinct and to the point. "They aren't filling up the hotels in Los Cabos," she explained, "so why would we want more hotel rooms?" Her complaint is common in Cabo Pulmo and throughout the East Cape. Many residents question why a new mass tourism development should be built on the East Cape when Los Cabos has so many empty hotel rooms. One of the underlying critiques in this argument is that Los Cabos might not be working as well as many say it is. If there are so many empty hotel rooms, then what was the point of building them — and why create even more out on the East Cape? Beyond that, she adds: "Why would we want a city right next to us?" Angeles also expresses her fears about what would happen if a large development project were to be built next to Cabo Pulmo. She worries about security, pollution, and the scarcity of fresh water. As with many others, for Angeles, Los Cabos is an important reference point she uses to gauge her understandings of the risks and benefits of development. If projects like Cabo Cortés are allowed, she thinks her own pueblo will go down the same path as Los Cabos. "I love my pueblo as it is," she tells me, adding "I don't want to see this in my pueblo." For Angeles, Los Cabos provides a vision of one possible future-and it's a vision she explicitly rejects.

Angeles is not alone. Judith, mentioned above, speaks of the cordones de miseria that surround the Los Cabos tourism corridor. These are the places where workers, squatters, and migrants from other parts of Mexico land in their quest to find employment in the tourism economy. These people live in dramatically different conditions than the bright, luxurious, air-conditioned hotels that dominate the coastlines of many high-end tourism destinations, including Los Cabos (see Castellanos 2010; López et al. 2006; Madsen Camacho, 2000). "There are many people who live in that area who don't have water," Judith said. "They live in Los Cabos, one of the most famous tourism spots in the world, and they don't have water, they don't have health services-this is ironic...and the developers don't see all of this, or if they do see it, they close their eyes." Judith highlights yet another powerful argument against the view that Los Cabos is a rousing success. The dividends of tourism development are not shared equally; the prevalence of urban colonias around the Los Cabos tourism zone makes this reality all too clear. Inequality is an intrinsic part of the mass tourism 
models that shape destinations such as Los Cabos. Like Angeles, this is not a future that Judith wants for her community.

Bertha, a professor of economics at the nearby university in La Paz, has deep roots on the East Cape. Her grandparents once owned land in Las Barracas, which is just around the bend from Cabo Pulmo. They had to sell their land in the mid 1970s because of her grandfather's declining health. Bertha laments this loss, and still feels strongly connected to the place she remembers from her childhood. Today, she is a prominent scholar whose work focuses on local history, economics, and development. She is also heavily involved in community organizations that work to protect and preserve the East Cape, including Cabo Pulmo. When we talked in June 2012, Bertha spoke about the negative side of Los Cabos. "I had the opportunity to work in Los Cabos in the 1970s at the beginning of the FONATUR development projects," she explained. "And it was really horrifying. To see how the people began to arrive, and how the local population started to ... lose that local place." Bertha's point resonates with her own experiences of dispossession-the rapid expansion and growth of Los Cabos resulted in the displacement of many local residents. "I wish from the bottom of my heart that I could stop these grand processes of urbanization and investment, which attract all these flows [of people] and become uncontrollable." For Bertha, Los Cabos portends a future in which local people lose control of and access to the places they know and love. This dispossession is the other face of the "exclusivity" promoted by many of the Los Cabos resorts.

Like inequality, this loss of access to place is also an intrinsic part of local social critiques of Los Cabos, as Oscar's story explains. Oscar is an organic produce vendor who lives and works on the East Cape, including Cabo Pulmo. When we talked in 2012, he spoke eloquently of the problems he imagined would result if the Cabo Cortés development became a reality. Like Angeles, he explicitly draws from his experiences with Los Cabos to evaluate future projects like Cabo Cortés. The big issue, he explained, is that places become inaccessible because of mass tourism development:

In San Lucas it used to be really beautiful ... but now you can't access [the coast] —it's all closed off ... People talk about progress and jobs, but it hasn't really happened. Los Cabos used to be affordable and cheap, but not now. In fact, Cabo San Lucas is a mess.

But he wasn't just talking about the physical closure of spaces, although that is indeed part of what is happening there, as formerly public beaches become de facto private spaces. Oscar also talked about social exclusion—he's not the kind of person that Los Cabos was built for, he tells me.

These local critiques of Los Cabos provide us with negative information about what people want in terms of development. These narratives tell us what people don't want to see happen in Cabo Pulmo and out on the East Cape. They are one side of local social discourses. Sustainability, I argue, is the other side. Local residents use the idea of sustainability to talk about what they do want, and what they hope for. The symbolic role of Los Cabos as the implicit antithesis of sustainability was made apparent during a DAI-led community meeting I attended in Cabo Pulmo in May 2012. The DAI staff opened the meeting with a question about what people liked most about Cabo Pulmo. There were varied responses. Some talked about kayaking, or the fact that dogs can run free on the beaches; others mentioned the starry night sky. Yet another person said that Cabo Pulmo is a "sanctuary with a unique group of people that must be preserved" and a representation of "hope that we can come up with a sensible plan to preserve this place." Then one woman raised her hand. "I love Cabo Pulmo," she said, "especially compared to what happened in Cabo San Lucas." This started a quick tumble of responses, which began to set the positive symbolism and meanings of Cabo Pulmo against the negative perceptions and opinions of Los Cabos. One woman explained how she likes the fact that Cabo Pulmo has no high-rise buildings. Yet another woman chimed in: "Cabo Pulmo means hope", adding that in her view the DAI plan is all about "creating an alternative to the kind of development that has happened in Los Cabos."

"The goal of DAI," said one of the staff members, "is to avoid the Cabo San Lucases of the world." Cabo Pulmo, for some, is the staging ground of possibility where that might just happen. It is a symbol of hope. Sustainable development is the plan—the hopeful idea—for getting this done. Sustainability seems to 
take on an almost magical quality in the community, offering an almost endless hope for alternative possibilities. It's an idea that appeals across the entire social spectrum in Cabo Pulmo, from long-time Mexican residents to recently arrived expats. This widespread social purchase is particularly noteworthy, since the social order of Cabo Pulmo is so thoroughly riddled with feuds, factions, and divisions.

Despite these internal divisions, belief in the power of sustainability have captured allegiance from all sides of the community. The local ideology of sustainability is able to work across and through seemingly insurmountable social borders and divisions. It is a point of agreement that moves, fluidly, across cracks in the social order. Even long-time enemies place hope in the belief that sustainability is the key to the future. In late 2012, however, a broad coalition of experts attempted to introduce a new concept-'regenerative design'-to replace the conceptual, material, and practice limitations of sustainability and sustainable development. This new concept was meant to transform ways of thinking about the future of the East Cape. But it was not to be. The story of what happened helps illustrate how the concept of sustainability is not only widely accepted, but also defended as an important component of the local ideological and social order.

\section{Rallying around sustainability}

In early November 2012 I attended a four-day meeting hosted by the newly created Sustainable Pueblos Project (SPP). ${ }^{4}$ The group was composed of a diverse collection of development experts, activists, planners, community members, NGO representatives, scientists, economists, architects, and others who had a vested interest in the development future of the East Cape. The primary goal of the SPP was to create, through a collaborative process, an alternative development proposal that could challenge and replace Cabo Cortés. As the project progressed through a series of meetings that took place throughout 2012 and 2013, the concept of sustainability became one of the key focal points for SPP's final project proposal, which was completed by the end of 2013.

Sustainability was not one of the dominant concepts that drove the group from the start, however. The term itself did not appear as part of the formal name of the project until the third meeting. The project was initially given a name based loosely upon the idea of 'alternative development.' There was debate, especially among some of the core architects and planners, about using the term 'sustainable development' versus using the newer concept of 'regenerative design.'

Edward $^{5}$, an architect from the US who was one of the key organizational figures of the project, explained the difference between the two concepts in one of the initial presentations at the meetings. The contrast, he explained, is between trying to maintain a place (i.e. sustainable development) versus trying to create a form of development that leads to the renewal of place (regenerative design). The core idea of regenerative design, Edward explained, is the shift from objects to systems, or from mechanistic models to a "living systems mindset." His idea, in effect, was to promote a development strategy that moved away from static models toward a plan that attempted to actually shape the environment in a "positive" way.

Edward talked about finding a model for growth that did not destroy Cabo Pulmo. He spoke of cocreation between human and natural systems. He wanted people to think in terms of community, rather than "projects." "How can tourism be something more than just an exploitative economy?" he asked. The idea of regenerative design, Edward explained, is a "new lens" for development, one that envisions profit as only one of many crucial considerations. Those other considerations include human capital, natural capital, etc. - all of these should be equally taken into account, he argued. At the end of the presentation, he asked "How productive is it to keep talking about all these plans and projects if the civil society has not been fertilized?"

The presentation moved the audience. There was a round of strong applause and commentary after the presentation. People seemed impressed — if not slightly confused by the complexity of the term. The overall response was mixed, but Edward's concept seemed to hold sway. The concept of regenerative development/design dominated the first couple of meetings and shaped the overall mission of the project. This was, in part, because sustainable development was initially seen as not going far enough. This was a

\footnotetext{
${ }^{4}$ Not the real name of this project.

${ }^{5}$ Pseudonym.
} 
point that Edward made repeatedly and it resonated with many group members, at least initially. Over time, however, the new concept of regenerative design began to lose traction to the more widely accepted concept of sustainability. The battle was finally and decisively won during a community meeting that took place in the community of Cabo Pulmo-a place that many saw as the symbolic heart of the whole SPP project.

The meeting started just before sunset at the Casa del Tamarindo, which is the headquarters of ACCP. There were about twenty from the SPP group at the meeting, and approximately eight community members from Cabo Pulmo - most of them associated with ACCP. A large circle of white plastic chairs was arranged under the tamarind tree. Kids were running around playing, laughing, as the sun slowly set. The mosquitoes were out. People intermittently slapped at them in a never-ending, small war. Michael, as the main organizer of SPP, served as the mediator between the various competing beliefs, interests, and opinions within the group, whose membership was dominated by outside experts, scientists, developers, planners, and investors. Local community members were part of the project, but they represented only a small fraction of the total group. This trip to Cabo Pulmo was an attempt to listen to local voices.

Michael introduced himself and the overall idea behind SPP's mission: to create an alternative to Cabo Cortés. At this point, regenerative design was still the dominant conceptual framework for the group. Judith spoke next. She said she was glad to see all of the people and experts who are taking time to work on this project. But, she said, we really need to listen to people from Cabo Pulmo. Judith set the stage for the conceptual battleground.

After she spoke, she indicated that she wanted Don Pedro ${ }^{6}$, one of the primary elders of the community, to speak next. But he declined, instead urging his son, Diego ${ }^{7}$, to speak instead. Diego was a little hesitant, but then said: "I have ideas, but I want to hear the ideas from these experts." He wavered, then continued, saying he wants to see development at Punta Arena/Cabo Cortés as "natural as possible." Michael stepped up and encouraged Diego to share more of his ideas. Diego then added, "I would want something smaller, cabañas, sustainable, ecological." Again, he said, he would like to hear about more examples and possibilities. The see-saw between competing concepts had begun, albeit in a subtle way. But Diego had introduced sustainability into the arena.

An economist from Mexico, one of the experts from SPP, speaks next. He says the most important thing is that the beauty of the place is for everyone-it should be accessible. So that all people-Canadian, American, Japanese, local—can access and preserve Cabo Pulmo. Keep it open, he says, that's the most important part.

Finally, Don Pedro steps in. He says he thinks that everyone is going to "focus on the same channel" and that "everyone wants sustainable development." Cabo Pulmo will get developed, he says. There were many years of fighting for the conservation of the park-it was terrible to see how much destruction there was [on the reef]. "It's necessary to create something more organized," he said, "to create something that protects places that are heavily visited. We are all focused on the same problem and mission ... it's important to remain firm about the kind of development that's coming in." Gracias a ustedes [thank you to you all], he says as he finishes. Everyone applauds and Don Pedro sits back down. With that, regenerative design was dead. Sustainability had won. The floodgate was open. It remains a little uncertain exactly why the tide turned at this point, but it clearly did. The newness of regenerative design, combined with its abstractness, may have been part of its downfall. But it appears that Don Pedro, as a community member of high standing - and an important symbolic leader in the eyes of SPP leadership-helped seal the fate of the new concept, in favor of the more familiar concept of sustainability.

Immediately, others join in, reaffirming the social power of sustainability. Panchito ${ }^{8}$, a younger fisherman and dive guide from Cabo Pulmo says: "We all want the same: sustainable development." Angeles speaks next. She says she wants to see developments without golf courses and marinas. "I want to see a small resort that focuses on nature, cabanas, focuses on the ocean and sun." Panchito jumps back into the

\footnotetext{
${ }^{6}$ Pseudonym.

${ }^{7}$ Pseudonym.

${ }^{8}$ Pseudonym.
} 
conversation: "We need to get the government involved. We need to be a good example for the rest of Mexico. Don't make massive hotels. We need to be a model for the rest, for the other states of Mexico."

Michael speaks again. We don't have a lot of time to do this, he says, making it known that he thinks this group has to act quickly to achieve success. "But we have some time to organize, and everything depends on your ideas and our ideas." He invites all of the people of Cabo Pulmo [those present at the time] to be a part of the project in the coming months.

A local historian from San Jose del Cabo asks: "What do all of you want here in Cabo Pulmo?" Judith responds by talking about the sustainable community development plan that was created with the help of DAI. We want water, light, and schools, she says. She refers to the main DAI objectives. Judith adds, "We have to think outside Cabo Pulmo and include [surrounding communities such as] Santiago, Miraflores. We have to focus on the different qualities and strengths to create something in place of Los Cabos. We need to connect all these communities-it's a dream, but realities start with a dream."

The community meeting at Cabo Pulmo highlighted—overwhelmingly—that the concept of sustainable development holds powerful social meanings. In contrast to the concept of regenerative design introduced by the outside experts, sustainable development was (and continues to be) a highly charged term that serves as a rallying point, a starting point, and a potential bridge for social political action. The reason for this, I argue, is that sustainability was already a well-known concept that was being used by local NGOs, community groups, activists, environmentalists, and others for years. It is an established term, one that continues to appeal to community members because of its perceived social power.

During the SPP meeting in Cabo Pulmo, key members of the community spoke up, using the language of sustainability to express their hopes for the future. They also explained, in their own ways, what the concept means for them. They spoke in terms of basic infrastructure, schools, ecological developments, and nature. They talked about keeping development small-scale, and working with surrounding communities. Implicit in their responses was the idea of participation. They spoke of a kind of development in which they - the community - have a voice in shaping their own future. This is the kind of sustainability that stands up for community, in the name of empowerment, and against the commodified, decontextualized terms that dominate official policy discourses (see Escobar 2008:153).

Yet, the 'community' of Cabo Pulmo as represented at the SPP meeting is one subset of a larger, often fractured whole. These fractures could present dire problems in future. The ACCP-Castro faction is undeniably one of the most active and dominant voices in the community, and they often take it upon themselves to speak for Cabo Pulmo as a whole. This is a strategic, political act-and it is not without contestation. There are other factions in Cabo Pulmo, including many members of the expat community, who are unwilling to listen to or endorse the efforts of ACCP or its members. This discord comes from deep, divided social histories. Those histories reach back to conflicts about land-and rights - that continue to shape and infect the community today. These kinds of divisions can, over time, erode the possibility of collaborative community action.

In this context, the idea of sustainability works as a sort of ideological duct tape, serving to create social cohesion while also tamping down competing voices and interests. Ironically, discourses that portend to speak in the name of local participation end up papering over internal dissent, disagreements, and personal disputes. But they do this in the name of presenting a 'united front', along the lines of Nader's discussions of "harmony ideology" (Nader 1990). In Nader's case, ideological discourses covered over internal conflicts and disputes, presenting a picture of harmony to the outside world. This was, in part, a way of combating the effects of colonization and conquest via an ideology of a bounded community (Nader 1990: 310). Rather than painting a picture of social harmony, in Cabo Pulmo the widespread social attachment to sustainability presents, to the outside world, a community united in a common cause and vision. This "papering over" through the ideology of sustainability allows for a unified social order that helps the community of push forward —at least in the short term. It is a partial solution-much like duct tape-that manages to hold together in times of social stress. 


\section{Conclusion}

In the community of Cabo Pulmo, the concept of sustainability resonates beyond the concerns, politics, and interests of local residents. It works at many levels. The management plan for the national park speaks to sustainability. An entire edited volume dedicated to Cabo Pulmo focuses on the possibilities of sustainable development (Gámez 2008). It is a pillar of the DAI community development plan. The Mexican government has officially adopted the rhetoric of sustainable development. It is everywhere. As of early 2014, the revised version of Cabo Cortés (now called Cabo Dorado) has even jumped on the sustainability bandwagon, claiming to a project founded on the principles of sustainable development while still proposing the construction of a massive tourism city.

Sustainability seems malleable enough to mean just about anything. And yet, the ideology of sustainability continues to carry tremendous social meaning and power in Cabo Pulmo. It is a container of ideas, motives, beliefs, and values that's open enough to allow people to feel they are participating in positive, if not radical social change. It is a temporary social binding agent. But how long can it last? Is it, in the end, really just a matter of false consciousness, in which the people of Cabo Pulmo have fallen prey to a corrupt belief system?

As Gámez (2008) argues, Cabo Pulmo has all of the elements that could make it an exemplar of sustainable tourism development. The potential is there. It could be a model for tourism development that promotes conservation, respects the natural and cultural environment, and puts the needs of communities first. However, the question is whether or not development in the community will actually conform to the ideals of sustainability in any meaningful way (2008: 13). The community of Cabo Pulmo remains laden with divisions, problems, conflicts, and contradictions. These problems include a shortage of land (due to ongoing disputes and high real estate values), a lack of basic services (power, schools, and health care), and growing economic disparity. As Gámez and Montaño argue (2004: 7), Cabo Pulmo is at risk of reproducing the patterns of growth seen elsewhere in BCS, which has resulted in the displacement of local people and serious environmental degradation. It is, at present, a long way from the kind of alternative development that the ideology of sustainability is predicated upon.

In Cabo Pulmo, the ideology of sustainability expresses a desire to avoid the unwanted future promised by Los Cabos, Cancun, and other destinations around Mexico (and the world) that have been radically transformed to serve the global tourism market (Murray Mas 2015). The social meaning of sustainability stands in contradistinction to the political green-washing that characterizes much official development discourse. It appears to point the way to an (as yet undefined) alternative to the development machine that sometimes appears unstoppable. The ideology of sustainability works as a sort of point of agreement, a linguistic and social meeting ground in which people come together and decide they can work together to create something else. It works as a powerful bridge between the dominant Mexican families, more recent immigrants, expats, and outside interlocutors. In this way, it works in a Geertzian sense to promote solidarity in times of social stress. It is meant to bridge the gap between things as they are and as community members want them to be (Geertz 1973: 205). The ideology of sustainability works to create social solidarity in order to stand up against and resist other, competing ideologies and discourses (including, of course, ideological beliefs of the need for unending growth).

At the very same time, while this ideological formation serves supposedly egalitarian, communitybased interests, it also works against itself. As Eric Wolf explained, ideology is about meaning, but it is also about power and the maintenance of social order. The ideology of sustainability works to quell internal dissent in the name of community, while it also gives some members of the community a more powerful voice and presence. It gives them a chance to represent, to speak for the rest of the community. In this way, it serves to maintain certain power dynamics and divisions even while it combats others. This resonates with Eagleton's (1991) argument for a more complex understanding of the function(s) of ideology, and Nader's discussions about the social contradictions that come with strategic deployments of harmony ideology (1990).

In Cabo Pulmo, sustainability is a social and conceptual battleground. It is a heavily contested field of signification—or meaning - that plays out at multiple social levels, from the local to the global. At the 
community level, the ideology of sustainability is about local demands, desires, hopes, expectations, and selfdetermination. A sustainable future is one in which people are still able to access place and freely and participate in the development process. This hopeful future is one in which people have access to fundamental resources that satisfy basic human needs-such as clean water, education, and health care services. It is a future in which they have a secure connection to the land itself. It is an optimistic future, held together, in part, by the conceptual plasticity of sustainability. In the end, Cabo Pulmo's development future is far more contingent upon the amelioration of deep internal divisions (including disputes over land) and the creation of extended socio-political networks of support than it is on the slippery ideological dreams of sustainable development. As Geertz argues, entrenched social and political problems will not "...melt away before a political change of heart" (Geertz 1973: 228). Ideology is powerful, but something more will be needed. Yet, the ideology of sustainability persists. It continues to be a social vehicle for hope, optimism, and the dream of a better future in Cabo Pulmo. Sustainability continues to work... at least for now.

\section{References}

Aburto-Oropeza O., B. Erisman, G.R. Galland, I. Mascarenas-Osorio, E. Sala, and E. Ezcurra. 2011. Large recovery of fish biomass in a no-take marine reserve. PLoS One 6(8): 1-7.

Adams, W.M. 2007. Green development, $3^{\text {nd }}$ Edition. New York: Routledge.

Bryant, R.L. 1991. Putting politics first: the political ecology of sustainable development. Global Ecology and Biogeography Letters 1(6): 164-166.

Cabral Bowling, M.L. 1998. La soberanía y el fideicomiso de inmuebles para extranjeros en Baja California Sur. La Paz: UABCS.

Castellanos, M. B. 2010. A return to servitude. Minneapolis: University of Minnesota Press.

Clancy, M. 2001. Exporting paradise. New York: Pergamon.

Delsol, C. 2012. Cabo Pulmo's fight to save 'the world's aquarium.' SFGate. [Accessed December 10, 2014]. http://www.sfgate.com/mexico/mexicomix/article/Cabo-Pulmo-s-fight-to-save-the-world-s-aquarium3439831.php

Eagleton, T. 1991. Ideology. London: Verso.

Edelman, M, and A. Haugeraud. 2007. The anthropology of development and globalization. Oxford: Blackwell.

Escobar, A. 1995. Encountering development: the making and unmaking of the third world. New Jersey: Princeton University Press.

Escobar, A. 2008. Territories of difference: place, movements, life, redes. Durham: Duke University Press.

Gámez, A.E. 2008. Turismo y sustentabilidad a la vera de áreas naturales protegidas. In Gámez, A.E. (ed.) Turismo y sustentabilidad en Cabo Pulmo, BCS. San Diego: San Diego State University. Pp 11-30.

Gámez, A.E. 2012. Los Cabos: a historical account. In P. Ganster, O. Arizpe C., and A. Ivanova (eds.) Los Cabos: prospectives for a natural and tourism paradise. San Diego: San Diego State University Press. Pp 203-220.

Gámez, A.E. and P. Ganster. Traditional tourism in Los Cabos: opportunities and limitations of economic growth. In P. Ganster, O. Arizpe C., and A. Ivanova (eds.) Los Cabos: prospectives for a natural and tourism paradise. San Diego: San Diego State University Press. Pp 249-270.

Gámez, A.E. and B. Montaño. 2004. Turismo y actividades económicas sustentables en Baja California Sur. Alternativa de B.C.S. 51: 2-7.

Gardner, K. and D. Lewis. 1996. Anthropology, development, and the post-modern challenge. London: Pluto Press.

Geertz, C. 1973. The interpretation of cultures. New York: Basic Books.

Gerber, J. 2008. Turismo y sustentabilidad en Cabo Pulmo. In A.E. Gámez (ed.) Turismo y sustentabilidad en Cabo Pulmo, BCS. San Diego: San Diego State University. Pp 293-298. 
Goldman, M. 2004. Eco-governmentality and other transnational practices of a "green" World Bank. In R. Peet and M.J. Watts (eds.) Liberation ecologies: environment, development, social movements. New York: Routledge. Pp 166-192.

Greenpeace. 2010. Cabo Cortés: destruyendo el paraíso. Report. [Accessed December 14, 2014]. http://www.greenpeace.org/mexico/es/Footer/Descargas/reports/Oceanos-y-costas/Cabo-Cortesdestruyendo-el-paraiso/

Hart, K. 2011. Building a human economy: a question of value? Suomen Antropologi: Journal of the Finnish Anthropological Society 36(2): 5-17.

Hart, K. and V. Padayachee. 2010. Development. In K. Hart, J.L. Laville, and A.D. Cattani (eds.) The human economy. Malden: Polity Press. Pp 51-62.

Hiernaux, D. N. 1999. Cancún bliss. In D.R. Judd and S.F. Fainstein (eds.) The tourist city. New Haven: Yale University Press. Pp 124-142.

Instituto Nacional de Estadistica, Geografía, e Informática (INEGI). 2000. Conteo de Población 2000. Aguascalientes: INEGI.

Instituto Nacional de Estadistica, Geografía, e Informática (INEGI). 2005. Conteo de Población 2005. Aguascalientes: INEGI.

Instituto Nacional de Estadistica, Geografía, e Informática (INEGI). 2010. Conteo de Población 2010. Aguascalientes: INEGI.

Jackson, P. and A.H. Neely. 2014. Triangulating health: toward a practice of a political ecology of health. Progress in Human Geography 39(1): 47-64.

Larrain, J. 1979. The concept of ideology. Athens: University of Georgia Press.

Lee, M. 2011. Marine reserve sets new standard for recovery. UT San Diego. [Accessed December 10, 2014]. http://www.utsandiego.com/news/2011/aug/12/marine-reserve-sets-new-standard-recovery/

Li, T. 1996. Images of community: discourse and strategy in property relations. Development and Change 27(3): 501-527.

López-López, Á., J. Cukier, and Á. Sánchez Crispín. 2006. Segregation of tourist space in Los Cabos, Mexico. Tourism Geographies 8(4): 359-379.

Mennem, K. 2012. Mexico increases minimum wage for 2013. San Diego Reader. [Accessed December 10, 2014]. http://www.sandiegoreader.com/weblogs/news-ticker/2012/dec/18/mexico-increasesminimum-wage-for-2013/\#

Madsen Camacho, M. E. 2000. The politics of progress: constructing paradise in Huatulco, Oaxaca. PhD Dissertation, University of California, Irvine.

Murray Mas, I. 2015. The fishing footprint of a tourism-based economy: displacing seafood consumption from local to distant waters in the Balearic Islands. Journal of Political Ecology 22: 211-238.

Nader, L. 1990. Harmony ideology: justice and control in a Zapotec mountain village. Stanford: Stanford University Press.

National Geographic Traveller. 2009. 133 places rated. National Geographic Traveller Nov./Dec.: 48-70.

Neumann, R.P. 2005. Making political ecology. London: Hodder Education.

Nichols, C. 2014. Hidden hunger: a political ecology of food and nutrition in the Kumaon Hills. Ph.D. Dissertation, School of Geography and Development, University of Arizona.

Redclift, M.R. 2005. Sustainable development (1987-2005): an oxymoron comes of age. Sustainable Development 13: 212-227. Reprint 2006

Richter, M. and U. Weiland. 2011. Applied urban ecology: a global framework. London: John Wiley.

Robbins, P. 2004. Political ecology: a critical introduction. 1st edition. Oxford: Blackwell.

Saragoza, A.M. 2010. Golfing in the desert: Los Cabos and post-PRI tourism in Mexico. In D. Berger and A. G. Wood (eds.) Holiday in Mexico: critical reflections on tourism and tourist encounters. Durham: Duke University Press. Pp 295-319. 
Scripps Institute of Oceanography. 2011. Hidden Baja undersea park is the world's most robust marine reserve. Scripps Institute of Oceanography News. [Accessed December 10, 2014]. https://scripps.ucsd.edu/news/1922

Seliger, M. 1976. Ideology and politics. London: George Allen and Unwin.

Sen, A. 1999. Development as freedom. New York: Knopf.

Torres, R.M. and J.D. Momsen. 2005. Gringolandia: the construction of a new tourist space in Mexico. Annals of the Association of American Geographers 4(3): 261-281.

Vargas, J.A. 1994. Mexico's foreign investment act of 1993. Loyola of Los Angeles International and Comparative Law Review 16(4).

Veteto, J. 2014. Foreign ownership on Mexico's coasts: the proposed amendment to Article 27 of the Mexican constitution. Law and Business Review of the Americas 20(2): 325-333.

Watts, M.J. and R. Peet. 2004. Liberating political ecology. In R. Peet and M.J. Watts (eds.) Liberation ecologies: environment, development, social movements. $2^{\text {nd }}$ edition. New York: Routledge. Pp 3-47.

Weiant, P.A. 2005. A political ecology of marine protected areas (MPAs): case study of Cabo Pulmo National Park, Sea of Cortez, Mexico. Ph.D. Dissertation, University of California, Santa Barbara.

Wilson, T.D. 2008. Economic and social impacts of tourism in Mexico. Latin American Perspectives 35(3): 37-52.

Wolf, E. 1999. Envisioning power: ideologies of dominance and crisis. Berkeley: University of California Press.

Zarza, G. 2013. El problema de los accesos restringidos a las playas. NOTICABOS. [Accessed December 10, 2014]. http://noticabos.org/2013/07/31/accesos-restringidos-playas/ 